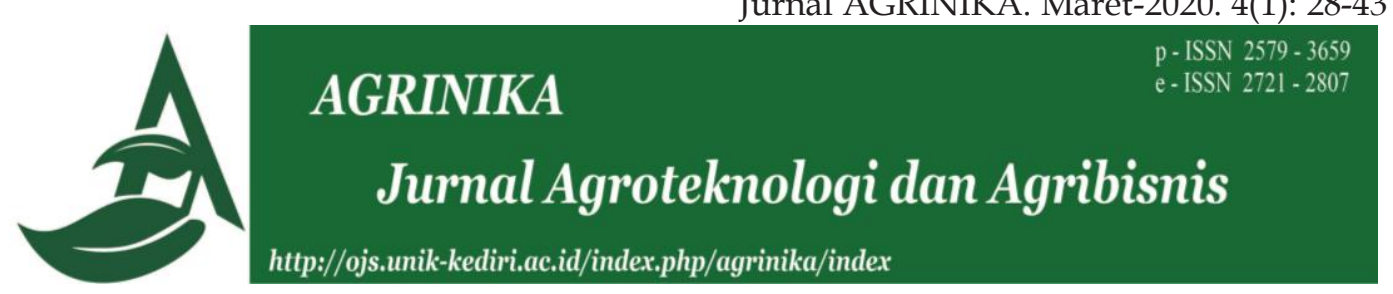

\title{
Budidaya perikanan skala kecil: Studi kasus ternak ikan gurami (Osphronemus gouramy) di Desa Mojosari Kecamatan Kras Kabupaten Kediri
}

\author{
Tri Widayatsih $^{1 *}$, Nina Lisanty ${ }^{2}$, Satriya Bayu $\mathrm{Aji}^{3}$, Agustia Dwi Pamujiati ${ }^{4}$ \\ ${ }^{1}$ Fakultas Perikanan, Universitas PGRI Palembang, Palembang, Indonesia \\ ${ }^{2}$ Fakultas Pertanian, Universitas Kadiri, Kediri, Indonesia
}

*Korespondensi: widayatsihtri@yahoo.com

Diterima 06 Januari 2020/Direvisi 18 Februari 2020/Disetujui 25 Februari 2020

\begin{abstract}
ABSTRAK
Studi ini meneliti sistem budidaya ikan gurami skala kecil berbasis kolam tanah di sentra budidaya ikan gurami di Kabupaten Kediri, yaitu Desa Mojosari Kecamatan Kras. Analisis ekonomi didasarkan pada data wawancara, observasi, dan dokumentasi yang dikumpulkan dari 30 peternak ikan gurami di lokasi penelitian. Dokumentasi data awal menunjukkan bahwa budidaya ikan gurami ditandai oleh periode budidaya yang cukup panjang. Meski dari observasi tampak bahwa budidaya ikan gurami ini dilakukan secara tradisional dengan sangat minimnya penggunaan teknologi tepat guna, kurang memperhatikan aspek mutu teknik budidaya, dan kurang efisien dalam penggunaan biaya produksi, hasil analisis data menunjukkan bahwa budidaya ini menguntungkan dan layak untuk diteruskan. Biaya total usaha rata-rata ternak ikan gurami pada kriteria luas kolam sempit sebesar Rp25.855.334,00 dan pada kriteria luas kolam luas rata-rata sebesar Rp44.170.834,00. Produksi rata-rata usaha ternak ikan gurami pada luas kolam sempit sebesar $1342 \mathrm{~kg}$ dan pada luas kolam luas sebesar $2157 \mathrm{~kg}$ dengan harga ikan sebesar Rp32.000,00 per kilogram. Total penerimaan rata-rata usaha ternak ikan gurami pada kriteria luas kolam sempit dan luas masing-masing sebesar Rp42.944.000,00 dan Rp69.024.000,00 dengan pendapatan rata-rata masing-masing sebesar
\end{abstract} Rp17.088.666,00 dan Rp24.853.666,00.

Kata kunci: Analisis biaya; Ikan gurami; Kelayakan usaha; Kolam tanah

\begin{abstract}
This study examined a small-scale gourami cultivation system based on soil ponds at a gourami cultivation center in Kediri Regency, namely Mojosari Village, Kras District. The economic analysis was based on interview, observation, and documentation data collected from 30 gourami farmers. Preliminary data documentation showed that gourami cultivation was characterized by a fairly long cultivation period. Although from observations, the cultivation of gourami was performed traditionally with minimal use of appropriate technology, less attention to the quality of cultivation techniques, and less efficient use of production costs, the results of data analysis show that this cultivation was profitable and feasible to continue. The total business cost of gourami on the criteria for a narrow pond was IDR 25,855,334.00 and in the criteria for an average pool area was IDR $44,170,834.00$. The average production of gourami in small-size pond was $1342 \mathrm{~kg}$ and in large-size pond was $2157 \mathrm{~kg}$ with fish price of IDR 32,000 per kilogram. The total average income of gourami farming on the criteria for small-size and large-size pond area were IDR 42,944,000.00 and IDR 69,024,000.00 respectively, with an average income of IDR $17,088,666.00$ and IDR $24,853,666.00$ respectively.
\end{abstract}

Keywords: Cost analysis; Feasibility; Gourami; Soil pond 


\section{PENDAHULUAN}

Ikan adalah sumber protein, nutrisi mikro, dan asam lemak yang penting bagi jutaan penduduk dunia (Kadir et al., 2006), yang berkontribusi terhadap asupan kalori harian. Terlepas dari keterbatasan informasi mengenai kontribusi budidaya perikanan skala kecil terhadap kehidupan petani dan ekonomi di negara berkembang, budidaya perikanan skala kecil pada kenyataannya termasuk salah satu sumber pendapatan yang dapat membantu mengentaskan kemiskinan, seperti contoh yang terjadi di SubSahara, Afrika (Kaliba et al., 2007).

Kabupaten Kediri merupakan salah satu daerah potensial budidaya perikanan. Hal ini terbukti dari data pada Pemerintahan Kabupaten Kediri, bahwa terdapat 124 desa di wilayah Kabupaten Kediri yang merupakan desa produsen perikanan dari 343 desa yang ada di 26 kecamatan. Kegiatan usaha perikanan ini terdiri dari usaha pembenihan ikan, budidaya ikan konsumsi, budidaya ikan hias, dan penangkapan ikan di perairan umum. Pada budidaya ikan konsumsi, komoditas ikan yang dibudidayakan adalah ikan lele, ikan gurami, dan ikan nila. Sedangkan untuk budidaya ikan hias, komoditas ikan yang dibudidayakan adalah ikan koi, ikan mas koki, ikan cupang, dan ikan komet.

Ikan gurami (Osphronemus gouramy) adalah jenis ikan air tawar asli perairan Indonesia yang sudah dikenal oleh hampir seluruh masyarakat Indonesia dan disukai sebagai ikan konsumsi tidak hanya di tanah air melainkan juga di Asia Tenggara secara umum. Selain dagingnya yang tebal dan bercita rasa gurih sehingga banyak diminati, kandungan gizi dan proteinnya juga cukup tinggi sebesar 19 persen dibanding dengan ikan lele, ikan nila, dan ikan mas yang masing-masing berkisar antara 18,2 persen, 16,1 persen, dan 16 persen (Irawan, 2016) Lebih dari itu, Irawan (2016) menambahkan bahwa ikan ini juga kerap dijadikan hiasan akuarium. Ikan gurami cukup mudah dibudidayakan dengan tidak terlalu banyak mengeluarkan banyak perawatan pada kondisi kolam dan harga jualnya pun cukup tinggi. Budidaya ikan gurami dapat dilakukan di kolam terpal, kolam semen, bahkan di kolam tanah.

Proses budidaya ikan gurami di Kabupaten Kediri umumnya berskala kecil dengan kolam buatan. Menurut AlBaiquni (2019), proses budidaya ikan gurami di Kabupaten Kediri meliputi persiapan kolam serta persiapan benih yang berkualitas, dan proses pemeliharaan ikan gurami yang baik hingga masa panen. Akan tetapi permasalahan yang sering terjadi pada kalangan peternak yaitu masa pertumbuhannya yang relatif lambat dibanding dengan ikan tawar lainnya. Ahmad et al. (2017) berpendapat bahwa lambatnya pertumbuhan ini didorong oleh faktor-faktor penyebab antara lain kualitas benih yang buruk, lingkungan yang kurang mendukung, dan pemberian pakan yang tidak sesuai takar kebutuhan ikan. Ditambahkan oleh Rano \& Yuningsih (2018), keterlambatan pertumbuhan inilah yang membuat pakan dipasok terus menerus dan masa panen yang begitu panjang sehingga perhitungan akan faktor biaya pun juga mencapai 60 hingga 70 persen.

Umumnya yang terjadi pada agribisnis skala kecil adalah pelaku, baik itu petani maupun peternak, dalam menjalankan usahanya tidak memahami biaya ekonomis (Fernandes \& Woodhouse, 2008). Kebanyakan petani 
atau peternak mengabaikan biaya-biaya seperti biaya kesempatan tenaga kerja, biaya penyusutan alat, dan biaya kesempatan penggunaan lahan (Thapa \& Niroula, 2008). Faktanya, biaya-biaya ini meningkat seiring dengan bertambahnya durasi budidaya (PonceMarban et al., 2006). Oleh karena itu, akan lebih menguntungkan untuk petani ataupun peternak apabila memiliki pemahaman mengenai struktur modal yang terlibat di dalam usahanya sehingga mereka dapat meningkatkan manajemen agribisnisnya. Di samping itu, penggunaan faktor produksi (input) yang efisien akan dapat memaksimalisasikan produksi melalui optimalisasi dari masing-masing input, asalkan pendekatan ini secara teknis memungkinkan. Artinya, seorang peternak ikan gurami harus memperhatikan besar kecilnya biaya yang dikeluarkan. Dalam usaha ternak ikan gurami inputnya pun harus diketahui mulai dari kondisi ikan, wadah budidaya yang baik, kondisi lingkungan yang memadai, pengelolaan air yang baik dan bersih, sampling, dan panen (Irawan, 2016). Hal ini bertujuan untuk mengurangi tingkat kegagalan pada peternak ikan gurami pada masa berbudidaya.

Studi ini memaparkan contoh bisnis yang meskipun minor dalam pandangan ekonomi, akan tetapi penting bagi kehidupan peternak atau pembudidaya perikanan skala kecil. Biaya dan pendapatan dianalisis karena kedua hal ini merupakan langkah awal penentuan keberhasilan dalam berbudidaya ikan gurami. Analisis dilakukan untuk memberikan gambaran mengenai produksi dan harga jual yang pada akhirnya berpengaruh pada pendapatan peternak ikan gurami dan keuntungan usaha ternak ikan gurami yang pada akhirnya usaha tersebut dapat dikatakan layak atau tidak untuk dilanjutkan.

\section{BAHAN DAN METODE}

\section{Metode Penelitian}

Metode penelitian merupakan cara ilmiah untuk mendapatkan data dengan tujuan dan kegunaan tertentu (Sugiono, 2018). Metode yang digunakan untuk memperoleh dan menganalisis data adalah metode kuantitatif yang didukung oleh data kualitatif. Dalam penelitian ini metode yang digunakan adalah survey, yaitu pengamatan atau penyelidikan terhadap satu kasus dan data yang diambil secara langsung. Penentuan lokasi penelitian dilakukan secara purposive (sengaja), yaitu Desa Mojosari Kecamatan Kras Kabupaten Kediri, dengan pertimbangan bahwa desa tersebut merupakan sentra budidaya ikan gurami dengan skala usaha kecil, 2000 hingga 3000 ekor ikan per kolam.

Penelitian dilaksanakan pada bulan Januari sampai Maret 2019. Pengambilan sampel penelitian dilakukan dengan menggunakan metode sensus terhadap populasi peternak ikan gurami sebanyak 30 orang responden. Metode pengumpulan data dilakukan dengan beberapa cara yakni: wawancara, observasi, dan dokumentasi. Wawancara atau kuisioner lisan adalah sebuah dialog yang dilakukan oleh pewawancara terhadap narasumber untuk memperoleh suatu informasi. Observasi dilakukan dengan pengamatan langsung pada objek penelitian berupa kondisi wilayah dan karakteristik responden untuk melengkapi data-data yang masih kurang lengkap. Selanjutnya, dokumentasi dilakukan untuk pengambilan data dengan 
mengumpulkan data yang berkaitan dengan penelitian. Jenis data yang digunakan adalah data primer dan data sekunder. Data primer diperoleh dari hasil pengamatan dan wawancara secara langsung kepada peternak ikan gurami. Sedangkan data sekunder diperoleh dari literatur yang mendukung penelitian dan lembaga-lembaga yang berkaitan dengan penelitian ini.

\section{Metode Analisis Data}

Untuk mengetahui biaya yang digunakan untuk produksi dan besarnya pendapatan peternak ikan gurami maka digunakan metode tabulasi. Metode tabulasi adalah proses pengelompokan jawaban yang sama dan cara mengumpulkannya dengan teliti dan teratur yang kemudian dihitung dan dijumlah berapa banyak peristiwa atau gejala dalam satu kategori. Selanjutnya, data diolah secara matematis dengan menggunakan program komputer dan kemudian disajikan dalam bentuk tabel untuk mempermudah deskripsi dan interpretasi data.

Untuk mengetahui besarnya pendapatan peternak ikan gurami di desa Mojosari Kecamatan Kras Kabupaten Kediri dilakukan analisis dengan rumus sebagai berikut (Soekartawi, 2005):

1. Total biaya

$\mathrm{TC}=\mathrm{TFC}+\mathrm{TVC}$

Keterangan :

$\mathrm{TC}=$ Total Cost, yaitu biaya total usaha budidaya ikan gurami $(R p)$

TFC = Fixed Cost, yaitu biaya tetap usaha budidaya ikan gurami (Rp)

TVC = Variabel Cost, yaitu biaya variabel usaha budidaya ikan gurami (Rp)

\section{Penerimaan}

$\mathrm{TR}=\mathrm{P} \times \mathrm{Q}$
Keterangan :

$\mathrm{TR}=$ Total Revenue (penerimaan total) usaha ternak ikan gurami (Rp)

$\mathrm{P}=$ jumlah produksi ikan gurami (ekor)

$\mathrm{Q} \quad=$ harga jual ikan gurami (Rp)

3. Pendapatan

$\pi=\mathrm{TR}-\mathrm{TC}$

Keterangan :

$\pi \quad=$ keuntungan atau pendapatan usaha ternak ikan gurami (Rp)

4. Analisis efisiensi usaha ternak ikan gurami

Untuk mengetahui efisiensi usaha ternak ikan gurami dapat digunakan R/C Ratio, yaitu perbandingan antara penerimaan dengan total biaya produksi ikan gurami. Selanjutnya untuk menguji kriteria tingkat efisiensi digunakan formulasi:

$R C=T R / T C$

Dengan kriteria:

$\mathrm{R} / \mathrm{C}=1$ artinya usaha ternak ikan gurami impas

$\mathrm{R} / \mathrm{C}<1$ artinya usaha ternak ikan gurami rugi

$\mathrm{R} / \mathrm{C}>1$ artinya usaha ternak ikan gurami menguntungkan

Untuk mengetahui usaha tersebut layak dijalankan atau tidak, maka dapat diketahui dengan menggunakan B/C Ratio.

$B / C=\pi / T C$

Dengan kriteria:

$\mathrm{B} / \mathrm{C}<0$ artinya usaha tidak layak secara finansial

$\mathrm{B} / \mathrm{C}=0$ artinya usaha layak tetapi belum maksimal

$\mathrm{B} / \mathrm{C}>0$ artinya usaha layak secara finansial 


\section{HASIL DAN PEMBAHASAN}

Karateristik Responden

Karakteristik

responden

memberikan gambaran mengenai keadaan pembudidaya ikan gurami, mulai dari usia, tingkat pendidikan, pengalaman berternak ikan gurami, modal yang digunakan, luas kolam yang ada, serta biaya-biaya yang digunakan dalam berternak. Karakteristik responden disajikan dalam Tabel 1 di bawah ini. Responden yang dijadikan sampel penelitian sebanyak 30 orang peternak.

Tabel 1. Karakteristik responden

\begin{tabular}{lrr}
\multicolumn{1}{c}{ Karakteristik } & Frekuensi (F) & Presentase (\%) \\
\hline Usia & & \\
$<50$ tahun & 24 & 80 \\
$>50$ tahun & 6 & 20 \\
Pendidikan & 8 & 27 \\
SD & 15 & 50 \\
SLTP & 7 & 23 \\
SLTA & & \\
Pengalaman & 7 & 23 \\
$<5$ tahun & 23 & 77 \\
$\geq 5$ tahun & & \\
Modal & 30 & 100 \\
Pribadi & 0 & 0 \\
Pinjam & & 90 \\
Luas Kolam & 27 & 10 \\
Sempit $<300 \mathrm{~m}^{2}$ & 3 & \\
Luas $\geq 300 \mathrm{~m}^{2}$ & & \\
\hline
\end{tabular}

Sumber : Data Primer diolah 2019

Berdasarkan tabel di atas diperoleh informasi bahwa responden Sebagian besar berumur kurang dari 50 tahun yakni sebanyak 24 orang dengan presentase sebesar 80 persen dan sisanya yang berumur 50 tahun atau lebih sebanyak 6 orang dengan presentase sebanyak 20 persen. Hal ini berarti usaha budidaya ikan gurami lebih banyak dilakukan oleh peternak yang berusia produktif, di bawah 50 tahun. Sementara itu, tingkat pendidikan terakhir responden di Desa Mojosari paling banyak pada tingkat SLTP (sekolah menengah pertama) yakni 15 orang dengan presentase sebesar 50 persen, kemudian 8 orang dengan presentase sebanyak 27 persen merupakan tamatan Sekolah Dasar, dan
7 orang merupakan tamatan Sekolah Lanjutan Tingkat Atas (SLTA). Tingkat pendidikan digunakan sebagai landasan keberhasilan dan pengetahuan akan budidaya ikan gurami.

Pengalaman yang dimiliki responden dari satu orang dengan lainnya juga berbeda-beda. Pengalaman sangat penting untuk mengetahui seberapa lama seseorang menekuni suatu usaha tersebut. Karakteristik pengalaman yang dimiliki responden sebagaimana ditampilkan Tabel 1 adalah sebagian besar sebanyak 23 orang (77 persen) berpengalaman di atas 5 tahun, sementara sisanya 7 orang berpengalaman di bawah 5 tahun.

Modal adalah biaya awal yang digunakan untuk memulai usaha. Modal 
usaha ternak ikan gurami meliputi semua biaya dari semua faktor produksi. Biaya-biaya ini terdiri dari biaya pembuatan kolam, pembelian benih ikan, pakan, vaksin dan obat, pajak, listrik, tenaga kerja, biaya transportasi, biaya pada saat panen, dan biaya pembelian perlengkapan, serta kebutuhan lain dalam berbudidaya. Modal ada yang berasal dari dana pinjaman atau ada juga dari dana milik pribadi. Berdasarkan wawancara diketahui bahwa 100 persen responden menggunakan dana milik pribadi untuk usahanya. Para responden mengakui bahwa usaha ternak ikan gurami yang mereka geluti merupakan usaha sampingan untuk tambahan pendapatan rumah tangga. Mata pencaharian utama responden adalah petani dan pedagang.

Luas kolam yang dimiliki oleh tiap responden berbeda-beda. Ada responden yang memiliki kolam yang luas dan berjumlah banyak, ada pula yang memiliki kolam dengan luas yang sempit. Luas kolam juga menentukan seberapa banyak benih ikan yang dapat dibudidayakan. Ikan gurami merupakan ikan yang suka dengan kolam yang dalam dan sifat ikan ini adalah sesekali muncul ke permukaan air. Kategori kolam luas di Desa Mojosari dapat menampung ikan sekitar 3000 ekor ikan atau lebih. Karakteristik luas pemilikan kolam di Desa Mojosari adalah bahwa responden yang memiliki luas kolam kategori luas, yaitu lebih dari $300 \mathrm{~m} 2$ sejumlah 3 orang dengan presentase sebesar 10 persen dan 90 persen responden di daerah penelitian memiliki luas kolam kategori sempit, yaitu di bawah $300 \mathrm{~m} 2$ sejumlah 27 orang.

\section{Biaya Usaha Ternak Ikan Gurami}

Biaya yang dikeluarkan untuk berwirausaha ikan gurami terdiri dari biaya tetap (fixed cost) dan biaya tidak tetap (variable cost). Biaya tetap adalah suatu biaya yang jumlahnya tidak tergantung pada besar kecilnya kuantitas produksi. Biaya tetap usaha ternak ikan gurami, meliputi biaya penyusutan kolam, biaya penyusutan alat, dan biaya pajak tanah di mana kolam dibuat. Biaya pajak tanah adalah biaya yang dibayar setiap tahunnya oleh pemilik lahan kepada negara. Banyaknya jumlah yang harus dibayarkan tergantung pada luas lahan yang dimiliki pemilik lahan. Jika lahan yang digunakan untuk berwirausaha adalah lahan sewa, maka setiap tahunnya harus membayar kepada pemilik lahan yang sesungguhnya dan umumnya dinamakan biaya sewa lahan. Secara detail, biaya tetap disajikan pada Tabel 2 di bawah ini.

Tabel 2. Biaya tetap usaha ternak ikan gurami berdasarkan kriteria luas kolam di Desa Mojosari Kecamatan Kras Kabupaten Kediri

\begin{tabular}{clrr}
\hline \multirow{2}{*}{ No } & \multirow{2}{*}{ Biaya Tetap } & \multicolumn{2}{c}{ Kriteria Kolam } \\
\cline { 3 - 4 } & & Sempit (Rp) & \multicolumn{1}{c}{ Luas (Rp) } \\
\hline 1 & Penyusutan Kolam & 849.537 & 875.000 \\
2 & Pajak & 470.000 & 1.050 .000 \\
3 & Penyusutan Alat & 1.441 .278 & 1.492 .500 \\
\hline & Total & $\mathbf{2 . 7 6 0 . 8 1 5}$ & $\mathbf{3 . 4 1 7 . 5 0 0}$ \\
\hline
\end{tabular}

Sumber: Data primer diolah 2019

Berdasarkan tabel di atas, biaya penyusutan dari kolam pada kriteria luas kolam sempit rata-rata per kolam sebesar Rp849.537,00 dan biaya 
pembuatan kolam pada luas kolam luas rata-rata per kolam sebesar Rp875.000,00. Sementara itu, biaya pajak tanah pada kriteria luas kolam sempit rata-rata per kolam sebesar Rp470.000,00 dan biaya pajak tanah pada kriteria luas kolam luas rata-rata per kolam sebesar Rp1.050.000,00.

\section{Sejumlah peralatan yang} digunakan selama proses budidaya ikan gurami berlangsung meliputi pompa berbahan bakar minyak, pompa listrik, jaring, pipa, bak, selang, dan lainnya. Biaya dari masing-masing peralatan ini kemudian disusutkan dengan memperhitungkan umur ekonomis peralatan tersebut. Biaya penyusutan peralatan pada kriteria luas kolam sempit rata-rata per kolam sebesar Rp1.441.278,00 dan pada kriteria luas kolam luas rata-rata per kolam sebesar Rp1.492.500,00.

Selain biaya tetap, biaya lainnya adalah biaya tidak tetap. Biaya ini dapat berubah-ubah sepanjang proses budidaya berlangsung dan tergantung pada besar kecilnya skala usaha. Biaya tidak tetap pada tabel di atas terdiri dari biaya benih ikan, biaya pakan, biaya tenaga kerja, biaya obat atau vaksin, biaya transportasi, dan biaya listrik. Lebih detail mengenai biaya tidak tetap berdasarkan pada kriteria luas kolam sempit dan kriteria luas kolam luas dapat dilihat pada Tabel 3 di bawah ini.

Tabel 3. Biaya tidak tetap usaha ternak ikan gurami berdasarkan luas kolam di Desa Mojosari Kecamatan Kras Kabupaten Kediri

\begin{tabular}{llrr}
\hline \multirow{2}{*}{ No } & \multirow{2}{*}{ Biaya Tidak Tetap } & \multicolumn{2}{c}{ Kriteria Kolam } \\
\cline { 3 - 4 } & Benih & Sempit (Rp) & \multicolumn{1}{c}{ Luas (Rp) } \\
\hline 1 & Pakan & 3.008 .778 & 6.600 .000 \\
2 & Tenaga kerja & 6.620 .000 & 14.520 .000 \\
3 & Obat & 0.545 .185 & 15.190 .000 \\
4 & Transport & 55.185 & 116.667 \\
5 & Biaya listrik & 590.741 & 476.667 \\
6 & Total & 2.234 .630 & 3.850 .000 \\
\hline & Total & $\mathbf{2 3 . 0 9 4 . 5 1 9}$ & $\mathbf{4 0 . 7 5 3 . 3 3 4}$ \\
\hline
\end{tabular}

Sumber: Data primer diolah 2019

Biaya pakan adalah sejumlah biaya yang digunakan peternak untuk membeli benih ikan yang akan ditebar ke kolam pembesaran. Benih ikan yang dibeli peternak berukuran rata-rata 2 hingga $3 \mathrm{~cm}$ dengan harga Rp1.500 per ekor. Dalam satu kolam umumnya dapat menampung ikan sekitar 2000 hingga 3000 ekor ikan, tergantung pada luas kolam. Biaya benih berdasarkan kriteria luas kolam sempit rata-rata per kolam sebesar Rp3.008.778,00 dan pada kriteria luas kolam luas rata-rata per kolam sebesar Rp6.600.000,00.
Biaya tenaga kerja adalah biaya yang dikeluarkan peternak untuk membayar seseorang yang dipekerjakan dengan nominal HOK (Hari Orang Kerja) yang berbeda-beda. Biaya tenaga kerja yang dikeluarkan untuk pembuatan kolam di Desa Mojosari rata-rata sebesar Rp50.000,00 per orang dan lamanya pekerjaan pembuatan kolam berkisar antara 3 hingga 7 hari. Biaya pemeliharaan kolam rata-rata per orang sebesar Rp40.000,00 selama proses budidaya. Biaya tenaga kerja pada saat panen dapat dihitung per orang dengan 
HOK sebesar Rp60.000,00. Biaya ratarata yang dikeluarkan untuk tenaga kerja berdasarkan kriteria luas kolam sempit rata-rata per kolam sebesar Rp10.545.185,00 dan pada kriteria luas kolam luas rata-rata per kolam sebesar Rp15.190.000,00.

Selanjutnya, biaya pakan adalah sejumlah biaya yang dikeluarkan untuk memenuhi kebutuhan pokok makanan pada ikan. Biaya pakan pada ikan gurami dapat diukur dari berapa banyaknya jumlah ikan yang dibudidayakan. Peternak umumnya melakukan perhitungan kebutuhan pakan dengan menghitung kebutuhan pakan per 1000 ekor ikan yang dapat menghabiskan $30 \mathrm{~kg}$ pakan setiap bulannya. Satu karung pakan berisi 30 kg seharga kurang lebih Rp300.000,00. Biaya pakan pada kriteria luas kolam sempit rata-rata per kolam sebesar Rp6.620.000,00 dan pada luas kolam luas rata-rata per kolam sebesar Rp14.520.000,00. Selain pakan, peternak juga mengeluarkan biaya vaksin atau obat. Biaya ini digunakan untuk membeli serangkaian vaksin atau obat untuk ikan yang terkena penyakit. Penyakit yang ada pada ikan gurami rata- rata adalah penyakit mata besar dan cacar. Pengobatan penyakit pada ikan gurami secara tradisional biasanya dilakukan dengan cara ikan direndam di air garam selama 1-2 hari, apabila kondisi ikan membaik maka ikan akan dipindah ke kolam semula. Biaya vaksin pada kriteria luas kolam sempit rata-rata per kolam sebesar Rp95.185,00 dan pada kriteria luas kolam luas rata-rata per kolam sebesar Rp116.667,00.

$$
\text { Biaya transportasi yang }
$$

dikeluarkan peternak untuk keperluan saat pembelian pakan, panen ikan dan pada saat keperluan transportasi lainnya juga diperhitungkan. Alat transportasi yang biasanya digunakan adalah motor dan mobil bak terbuka atau truk. Biaya transportasi berdasarkan kriteria luas kolam sempit rata-rata per kolam sebesar Rp590.741,00 dan pada kriteria luas kolam luas rata-rata per kolam sebesar Rp476.667,00. Tidak kalah penting adalah biaya penggunaan listrik. Biaya listrik yang digunakan dalam berwirausaha ternak ikan gurami meliputi biaya yang digunakan dalam hal pergantian air setiap minggunya. Biaya listrik pada kriteria luas kolam sempit rata-rata per kolam sebesar Rp2.234.630,00 dan biaya listrik pada luas kolam luas rata-rata per kolam sebesar Rp3.850.000,00.

\section{Produksi dan Penerimaan}

Budidaya ikan gurami dilakukan dalam durasi yang bervariasi di antara responden. Durasi budidaya terpendek adalah 12 bulan, dan durasi terlama sekitar 18 bulan dimulai dari awal benih berukuran "silet" hingga mencapai berat lebih dari $0,5 \mathrm{~kg}$ per ekornya. Produksi ikan gurami yang dihasilkan dihitung dalam satuan kilogram, dengan harga ikan gurami per kilogramnya pada saat penelitian dilakukan adalah sebesar Rp32.000,00. Harga ikan gurami sangat fluktuatif tiap bulan dan tiap tahun. Ada bulan-bulan tertentu dalam setahun di mana harga bisa mencapai harga tertinggi. Harga terendah bisa mencapai Rp24.000,00 dan tertinggi hingga Rp.36.000,00. Produksi ikan gurami dikalikan harga yang berlaku akan menghasilkan suatu penerimaan. Lebih detail dapat dilihat pada Tabel 4 berikut ini. 
Tri Widayatsih, Budidaya Perikanan Skala ...

Tabel 4. Produksi dan penerimaan usaha ternak ikan gurami berdasarkan luas kolam di Desa Mojosari Kecamatan Kras Kabupaten Kediri

\begin{tabular}{lrr}
\hline \multirow{2}{*}{ Komponen } & \multicolumn{2}{c}{ Kriteria Kolam } \\
\cline { 2 - 3 } & Sempit & \multicolumn{1}{c}{ Luas } \\
\hline Produksi $(\mathrm{kg})$ & 1342 & 2157 \\
Harga $(\mathrm{Rp})$ & 32.000 & 32.000 \\
Penerimaan $(\mathrm{Rp})$ & 42.944 .000 & 69.024 .000 \\
\hline
\end{tabular}

Sumber: Data primer diolah 2019

Pada tabel di atas dapat diketahui bahwa pada kriteria kolam sempit ratarata per kolam menghasilkan produksi ikan sebesar $1342 \mathrm{~kg}$ dengan penerimaan sebesar Rp42.944.000,00. Sementara pada kriteria kolam luas ratarata per kolam menghasilkan produksi sebanyak $2157 \mathrm{~kg}$ dengan penerimaan sebesar Rp69.024.000,00.

\section{Pendapatan}

Pendapatan peternak dapat diketahui dari selisih antara total penerimaan dikurangi dari total biaya produksi. Pendapatan peternak ikan gurami berdasarkan kriteria luas kolam di Desa
Mojosari dapat dilihat pada Tabel 5 berikut ini.

Pada tabel 5 dapat diketahui bahwa pada kriteria kolam sempit terdapat total biaya rata-rata per kolam sebesar Rp25.855.334,00 dengan penerimaan sebesar Rp42.944.000,00 dan pendapatan sebesar Rp17.088.666,00. Sementara itu, pada kriteria kolam luas diketahui bahwa total biaya rata-rata per kolam pada kolam luas sebesar Rp44.170.834,00 dan penerimaan sebesar Rp69.024.000,00 menghasilkan pendapatan sebesar Rp24.853.166,00.

Tabel 5. Biaya total, penerimaan, dan pendapatan usaha ternak ikan gurami menurut luas kolam di Desa Mojosari Kecamatan Kras Kabupaten Kediri

\begin{tabular}{lcc}
\hline \multicolumn{1}{c}{ Komponen } & \multicolumn{2}{c}{ Kriteria Kolam } \\
\cline { 2 - 3 } & Sempit & Luas \\
\hline Biaya Total $(\mathrm{Rp})$ & 25.855 .334 & 44.170 .834 \\
Penerimaan $(\mathrm{Rp})$ & 42.944 .000 & 69.024 .000 \\
Pendapatan $(\mathrm{Rp})$ & 17.088 .666 & 24.853 .166 \\
\hline
\end{tabular}

Sumber: data primer diolah 2019

Kelayakan Usaha

Kelayakan suatu usaha dapat diukur dengan analisis perbandingan keuntungan dengan biaya-biaya yang digunakan dalam proses budidaya. Suatu usaha dapat dikatakan layak apabila nilai dari $\mathrm{B} / \mathrm{C}$ lebih dari nol. Apabila nilai dari B/C kurang dari nol maka usaha tersebut tidak layak dijalankan. Lebih lanjut, apakah usaha menguntungkan atau malah merugi dapat dilihat melalui nilai R/C. Nilai R/C yang lebih besar dari 1 mengindikasikan usaha ternak ikan gurami menguntungkan, sebaliknya untuk nilai $\mathrm{R} / \mathrm{C}$ sama dengan satu berindikasi impas, sedangkan nilai $R / C$ kurang dari satu berarti usaha ikan gurami merugi. Kelayakan usaha di Desa Mojosari dapat dilihat pada Tabel 6 di bawah ini. 
Tri Widayatsih, Budidaya Perikanan Skala ...

Tabel 6. Kriteria kelayakan usaha menurut luas kolam di Desa Mojosari Kecamatan Kras Kabupaten Kediri

\begin{tabular}{lrr}
\hline \multirow{2}{*}{ Komponen } & \multicolumn{2}{c}{ Kriteria Kolam } \\
\cline { 2 - 3 } & Sempit & \multicolumn{1}{c}{ Luas } \\
\hline Biaya Total (Rp) & 25.855 .334 & 44.170 .834 \\
Pendapatan (Rp) & 17.088 .666 & 24.853 .166 \\
Penerimaan (Rp) & 42.944 .000 & 69.024 .000 \\
B/C & 0,66 & 0,56 \\
R/C & 1,66 & 1,56 \\
\hline
\end{tabular}

Sumber : Data Primer diolah 2019

Pada tabel di atas dapat diketahui bahwa pada kriteria luas kolam sempit terdapat total biaya rata-rata sebesar Rp 25.855.334,00 dengan pendapatan rata-rata sebesar $\mathrm{Rp} 17.088 .666,00$ dan nilai dari $\mathrm{B} / \mathrm{C}$ sebesar 0,66 . Pada kriteria luas kolam luas terdapat total biaya ratarata sebesar $\mathrm{Rp} 44.170 .834,00$ dengan pendapatan rata-rata sebesar Rp24.853.166,00 dengan nilai dari B/C sebesar 0,56.

Semakin besar nilai R/C maka akan semakin besar pula keuntungan yang diperoleh pembudidaya ikan. Nilai $\mathrm{R} / \mathrm{C}$ ratio yang diperoleh pada budidaya pembesaran ikan gurami ini lebih besar dari 1 pada kedua kriteria kolam, yaitu masing-masing sebesar 1,66 dan 1,56 pada kriteria kolam sempit dan kolam luas. Hal ini berarti penggunaan biaya produksi dapat dikatakan cukup efisien. Hal ini juga menunjukkan bahwa budidaya pembesaran ikan gurami layak secara ekonomi untuk diusahakan. Sehingga dapat dikatakan semua biaya produksi yang dikeluarkan tertutup oleh penerimaan yang diperoleh pembudidaya.

\section{Uji T Keuntungan}

Uji t adalah salah satu alat uji statistika yang dipergunakan untuk menguji kebenaran hipotesis. Hasil pengujian statistika ditampilkan pada Tabel 7 .
Pada Tabel 7 dapat diketahui bahwa berdasarkan karakteristik luas kolam sempit t-hitung sebesar 27,298, yang berarti bahwa nilai tersebut lebih besar dari t-tabel sebesar 2,0555. Pada kriteria luas kolam luas t-hitung sebesar 7,174, yang berarti nilainya lebih besar daripada t-tabel 4,3027. Berdasarkan uji ini dapat disimpulkan bahwa hipotesis nol ditolak dan hipotesis penelitian diterima. Hal ini berarti bahwa penerimaan peternak gurami pada kolam sempit dan kolam luas tidak sama dengan total biaya yang dikeluarkan pada kolam sempit dan kolam luas sehingga dapat dikatakan bahwa usaha ternak ikan gurami di desa Mojosari menguntungkan dan layak untuk dilanjutkan.

\section{Penggunaan Teknologi Tepat Guna}

Berdasarkan wawancara, observasi, dan dokumentasi yang dilakukan pada penelitian ini, pada bagian ini akan dibahas kendala dan tantangan yang dihadapi responden dalam budidaya perikanan skala kecil. Pertama, teknologi yang digunakan pada budidaya ikan gurami di daerah penelitian (dan Kabupaten Kediri pada umumnya) cenderung masih bersifat sangat sederhana (tradisional). Tampak dengan sangat jelas terdapat kendala penggunaan inovasi teknologi tepat 
Tri Widayatsih, Budidaya Perikanan Skala ...

Tabel 7. Uji T keuntungan berdasarkan luas kolam sempit dan luas di Desa Mojosari Kecamatan Kras Kabupaten Kediri

\begin{tabular}{lcr}
\hline \multirow{2}{*}{ Komponen } & \multicolumn{2}{c}{ Kriteria Kolam } \\
\cline { 2 - 3 } & Sempit & \multicolumn{1}{c}{ Luas } \\
\hline Biaya Total (Rp) & 25.855 .334 & 44.170 .834 \\
Penerimaan (Rp) & 42.170 .834 & 69.024 .000 \\
Uji Statistika & 27,298 & 7,174 \\
\hline
\end{tabular}

Sumber: Data Primer diolah 2019

guna dari sumber daya manusia (peternak). Oleh karena itu, agar semakin dapat mengembangkan usaha budidaya gurami ini maka sudah selayaknya untuk mengarahkan teknik budidaya ini menuju usaha budidaya ikan gurami yang bersifat intensif, tetap dengan memperhatikan kriteria-kriteria yang terdapat dalam standar mutu budidaya yang ada.

Tingkat pendidikan peternak yang tergolong agak rendah memungkinkan rendahnya inisiasi dan kreativitas peternak dalam melakukan budidaya. Selain dari itu, penggunaan teknologi dan inovasi memang erat kaitannya dengan terbatasnya dana atau modal yang dimiliki oleh pembudidaya. Oleh karena itu dalam pelaksanaan budidaya dengan inovasi teknologi intensif tentunya akan membutuhkan peran serta dari pihak terkait, seperti pemerintah (dalam hal ini dinas-dinas terkait), stakeholder, dan bank atau koperasi sebagai penyedia fasilitas permodalan.

Peran aktif pemerintah, khususnya Dinas Kelautan dan Perikanan setempat mutlak diperlukan. Penelitian ini menunjukkan keterbatasan informasi peternak terkait budidaya ini, mengingat juga rendahnya tingkat pendidikan dan minimnya pengalaman peternak. Sehingga diharapkan dinas terkait dapat memberikan penyuluhan mengenai penerapan standard produksi yang kemudian disertai dengan pengawasan atau evaluasi pada masing-masing budidaya ikan gurami ini. Sebagaimana dinyatakan oleh Malika et al. (2012) bahwa kegiatan penyuluhan sebaiknya tidak hanya mengenai teknis budidaya saja, tapi lebih difokuskan pada pembinaan serta pendampingan secara bertahap yang disertai evaluasi untuk meningkatkan kemampuan pembudidaya dalam memahami standard teknik budidaya ikan gurami tersebut. Hal tersebut dirasa sangat perlu untuk dilakukan untuk mengubah pola pikir parsial mengenai teknik budidaya secara tradisional menuju modern dengan penerapan teknologi serta penerapan standard nasional secara berkelanjutan.

Selain pemerintah, peran kelembagaan lainnya juga diperlukan. Dari hasil wawancara, belum ditemukan adanya pembentukan kelompok peternak ikan gurami di lokasi penelitian. Apabila masing-masing desa produsen perikanan gurami di Kabupaten Kediri membentuk kelompok ternak, maka akan lebih baik sehingga akan dapat dibentuk kelembagaan gabungan kelompok peternak ikan gurami. Lembaga ini dirancang dan diharapkan dapat digunakan sebagai wadah pembelajaran dan sarana komunikasi antar anggota. Di samping itu, adanya sistem kelembagaan seperti ini akan dapat mempermudah peternak dalam mengembangkan sarana dan prasarana produksi, pemasaran, sistem permodalan atau pembiayaan, serta 
kemudahan mengakses perkembangan informasi mengenai teknik budidaya. Malika et al. (2012) menambahkan bahwa kelembagaan dapat meningkatkan pemahaman terhadap standar produk perikanan bagi para pembudidaya dalam rangka memperbaiki mutu produksi dan menghadapi tuntutan pasar.

\section{Teknis Budidaya}

Dari hasil observasi di lokasi penelitian, diperoleh kesimpulan akan kendala dan tantangan yang kedua, yakni mengenai teknis budidaya ikan gurami. Hal ini meliputi: jenis kolam budidaya, drainase kolam, penggunaan peralatan, kepadatan penebaran ikan ke dalam kolam, dan aplikasi serta jenis pakan ikan gurami.

Pemilihan kolam tanah untuk budidaya kurang sesuai kriteria standar mutu budidaya perikanan. Apabila melihat budidaya ikan gurami di Kabupaten Tulungagung, hampir tidak ditemukan lagi budidaya perikanan dengan kolam tanah. Peternak umumnya menggunakan kolam terpal (Virnanto et al., 2016). Hal ini mengingat kolam semen membutuhkan biaya yang lebih besar, maka kolam terpal cukup murah dan memiliki umur ekonomis yang lebih panjang, paling tidak 4 hingga 6 kali masa budidaya dibandingkan kolam tanah biasa. Kemudian instalasi pipa sederhana untuk air keluar dan masuk (drainase) juga perlu dibuat untuk mempermudah proses membersihkan dan sirkulasi air kolam. Hal ini diperlukan juga untuk mengurangi biaya pembelian alat pompa berbahan bakar minyak yang digunakan peternak pada saat membersihkan dasar kolam dari kotoran ikan gurami yang menumpuk.

Selanjutnya, teknis budidaya yang terkendala adalah kepadatan ikan di dalam kolam. Ikan yang dipelihara pada kepadatan yang rendah memiliki tingkat keagresifan yang lebih tinggi dalam memperoleh pakan jika dibandingkan dengan kepadatan yang tinggi (Abidin, 2009)a. Menurut Verawati et al. (2015) peningkatan kepadatan akan diikuti dengan penurunan pertumbuhan dan pada kepadatan tertentu pertumbuhan akan berhenti. Untuk mencegah hal tersebut, maka dibutuhkan informasi padat penebaran yang optimum sehingga dapat memberikan hasil yang optimal.

Dari hasil wawancara dengan responden, diperoleh informasi bahwa selama masa budidaya, peternak acap kali menjumpai keadaan di mana ikan gurami lambat makan atau tidak mau makan sama sekali. Menurut Badan Standarisasi Nasional (2000) dan Boyd (1990), hal ini dapat disebabkan oleh terjadinya penurun $\mathrm{pH}$ pada air kolam yang disebabkan semakin meningkatnya buangan metabolisme (cenderung asam dan mengandung ammonia) seiring meningkatnya padat penyebaran. Selain itu, penurunan $\mathrm{pH}$ disebabkan oleh peningkatan $\mathrm{CO} 2$ akibat proses respirasi. Ditambah lagi bahwa penurunan oksigen terlarut dalam media pemeliharaan berbanding lurus dengan banyaknya buangan metabolisme ikan. Sigantang dan Sarwono (2005) menganjurkan sistem resirkulasi untuk meningkatkan kadar oksigen terlarut dan mengurangi kadar ammonia dan limbah organik yang dihasilkan oleh ikan sehingga kualitas air dapat dipertahankan untuk kehidupan ikan. Diharapkan dengan semakin meningkatnya padat penebaran dan pengelolaan kualitas air pun harus membaik, sehingga produktivitas budidaya ikan gurami semakin meningkat dan layak, serta memperoleh 
keuntungan yang maksimal bagi peternak gurami itu sendiri.

Lebih lanjut Effendie (2004) menyatakan bahwa kualitas air (terutama oksigen, $\mathrm{pH}$, suhu dan amoniak) sangat berpengaruh terhadap efisiensi pakan, diikuti juga dengan faktor kebiasaan makan, ukuran, dan stadia spesies ikan. Menurunnya efisiensi pakan adalah sebagai akibat semakin tingginya padat penebaran yang menyebabkan ruang gerak ikan yang semakin sempit sehingga nafsu makan berkurang. Dalam kondisi stres, nafsu makan ikan menjadi menurun dan gangguan fungsi fisiologis semakin meningkat yang selanjutnya akan menurunkan efisiensi pakan.

Responden hanya menggunakan pakan pabrikan atau pakan buatan, meskipun kenyataannya gurami merupakan jenis ikan omnivora yang juga mengkonsumsi pakan alami hijauan di habitat aslinya. Hasil penelitian Kholifah (2015) mengungkapkan salah satu bahan pakan alternatif yang belum banyak dimanfaatkan, yaitu tumbuhan air azolla. Azolla dalam bentuk tepung dapat dipakai sebagai campuran pakan ikan dalam bentuk pellet. Azolla mempunyai kandungan protein kasar sebesar $19,54 \%$ dan memiliki serat kasar yang cukup tinggi, untuk meningkatkan kandungan protein dan mengurangi serat kasar dapat dilakukan dengan proses fermentasi. Pakan ikan yang baik biasanya pakan dengan kandungan protein yang lebih tinggi dibandingkan karbohidrat karena protein merupakan sumber energi utama bagi ikan. Komposisi pakan yang baik untuk ikan gurami yaitu protein 30 hingga 32 persen dan karbohidrat 20 hingga 30 persen (Helver dan Hardy, 2002).

\section{Efisiensi Produksi}

Kegiatan budidaya ikan gurami di

Desa Mojosari Kabupaten Kediri meskipun secara ekonomis layak dan menguntungkan, akan tetapi bila dihitung berdasarkan lamanya durasi budidaya tidak terlalu memberikan keuntungan yang banyak untuk tambahan pendapatan bulanan peternak. Meski demikian, mengingat pentingnya usaha budidaya ini bagi kehidupan peternak, dan melihat peluang permintaan pasar yang cukup banyak atas ikan gurami ini, budidaya ikan gurami sudah seharusnya mendapatkan perhatian lebih agar dapat terus berkelanjutan. Sehubungan dengan keberlanjutan usaha budidaya ini hingga masa yang akan datang, institusi terkait diharapkan mampu membantu mengurangi dampak kurang baik dari budidaya ini terhadap lingkungan. Chatchaipun et al. (2008) menyatakan bahwa kualitas sumber air yang dieksploitasi oleh komunitas peternak di suatu wilayah sentra produksi wajib untuk dipelihara. Hal ini karena produksi budidaya ikan gurami bergantung pada frekuensi pergantian air kolam, kuantitas dan kualitas pangan, kepadatan ikan dalam kolam, dan penggunaan vaksin dan obat-obatan (Chatchaipun et al., 2009).

Seperti dibahas sebelumnya bahwa umumnya kegiatan budidaya ikan gurami di Kabupaten Kediri masih dilakukan secara tradisional berdasarkan teknik budidaya yang diperoleh turun temurun. Hal tersebut dapat dilihat dari konstruksi kolam yang tidak beraturan, pemilihan jenis kolam tanah biasa, pemberian pakan dan penggunaan vaksin atau obat-obatan atau bahan kimia lainnya yang tidak sesuai dengan aturan, serta teknik/cara 
budidaya yang masih belum terukur. Hal tersebut menyebabkan tingkat perkembangan jumlah produksi ikan gurami menjadi semakin menurun. Sehingga meskipun harga ikan gurami dikenal sangat tinggi daripada ikan air tawar lainnya, namun kemungkinan laba yang diperoleh oleh para pembudidaya akan lebih rendah karena kurang memperhatikan aspek mutu teknik budidaya. Kondisi tersebut juga dapat mengindikasikan adanya penggunaan biaya-biaya produksi yang kurang efisien.

\section{KESIMPULAN}

Karakteristik responden yang merupakan peternak ikan gurami di Desa Mojosari adalah sebagai berikut:

a. Usia yang paling banyak berwirausaha ternak ikan gurami adalah pada usia kurang dari 50 tahun dengan presentase sebesar 80 persen.

b. Pendidikan responden rata-rata lulusan SLTP dengan presentase sebesar 50 persen.

c. Luas kolam yang dimiliki responden rata-rata seluas kurang dari $300 \mathrm{~m} 2$ dengan presentase sebesar 90 persen.

Biaya total usaha rata-rata ternak ikan gurami pada kriteria luas kolam sempit sebesar Rp25.855.334,00 dan pada kriteria luas kolam luas rata-rata sebesar Rp44.170.834,00. Produksi rata-rata usaha ternak ikan gurami pada luas kolam sempit sebesar $1342 \mathrm{~kg}$ dan pada luas kolam luas sebesar $2157 \mathrm{~kg}$ dengan harga ikan sebesar Rp32.000,00 per kilogram. Total penerimaan rata-rata usaha ternak ikan gurami pada kriteria luas kolam sempit dan luas masingmasing sebesar Rp42.944.000,00 dan Rp69.024.000,00 dengan pendapatan rata-rata masing-masing sebesar Rp17.088.666,00 dan Rp24.853.666,00.

Nilai R/C dan B/C rasio rata-rata pada kriteria luas kolam sempit dan luas masing-masing sebesar 1,66 dan 0,66 serta 1,56 dan 0,56 . Dari nilai $R / C$ dan $\mathrm{B} / \mathrm{C}$ pada kedua kriteria luas kolam dapat diketahui bahwa usaha ternak ikan gurami di lokasi penelitian menguntungkan dan layak untuk dilanjutkan.

Untuk mengurangi tingkat kematian pada ikan gurami di Desa Mojosari, sebaiknya diadakan sosialisasi dan penyuluhan kepada seluruh peternak ikan gurami tentang pentingnya penggunaan teknologi tepat guna, dan informasi teknis budidaya yang tepat sehingga produksi lebih efisien, tingkat kegagalan panen dan kematian pada ikan dapat berkurang, dan peternak dapat memperoleh keuntungan usaha yang lebih banyak.

\section{DAFTAR PUSTAKA}

Abidin, Z. (2009). Kinerja produksi benih gurami osphronemus gouramy lac ukuran $8 \mathrm{~cm}$ dengan padat penebaran 3, 6 dan 9 ekor/liter pada sistem resirkulasi. IPB.

Ahmad, N., Martudi, S., \& Dawami. (2017). Pengaruh kadar protein yang berbeda terhadap pertumbuhan ikan gurami. Jurnal Agroqua, 15(2), 51-58.

Al-Baiquni, B. J. (2019). Analisis structure-conduct-performance pasar ikan gurami (osphonemus gouramy) di Kabupaten Kediri. Journal of Economic and Social of Fisheries and Marine, 6(2), 134148.

Badan Standarisasi Nasional. (2000). 
Standar Nasional Indonesia. SNI: 6485.1-2000. Induk Gurami (Osphronemus gouramy, Lac) Kelas Induk Pokok (Parent Stock).

Boyd, C. E. (1990). Water quality in ponds for aquaculture. Auburn University.

Chatchaipun, S., Na-Nakorn, U., Isvilanonda, S., \& Niyomthai, C. (2008). Economic analysis of giant gouramy (Ospheronemus gouramy) production in Uthai Thani Province, crop year 2005/2006. Kasetsart University Fisheries Research Bulletin, 32(1), 11-22.

Chatchaipun, S., Niyomthai, C., Isvilanonda, S., \& Na-Nakorn, U. (2009). Small scale aquaculture: a case study on giant gouramy (Ospheronemus gouramy) culture in Uthai Thani Province, Thailand. Kasetsart University Fisheries Research Bulletin, 33(3), 32-43.

Effendie, M. I. (2004). Pengantar akuakultur. Penebar Swadaya.

Fernandes, L. A. O., \& Woodhouse, P. J. (2008). Family farm sustainability in southern Brazil: an application of agri-environmental indicators. Journal of Ecological Economics. https://doi.org/10.1016/j.ecolecon.2 008.01.027

Irawan, P. (2016). Cara mudah dan benar beternak ikan gurami. Air Publishing.

Kadir, A., Kundu, R. S., Milstein, A., \& Wahab, M. A. (2006). Effects of silver carp and small indigenous species on pond ecology and polycultures in Bangladesh.
Aquaculture, 261, 1056-1076.

Kaliba, A. R., Ngugi, C. C., Mackambo, J. M., Osewe, K. O., Senkondo, E., \& Mnembuka, B. V. (2007). Potential effect of aquaculture promotion on poverty reduction in Sub-Saharan Africa. Journal of Aquaculture International, 15, 445459.

Kholifah, T. (2015). Potensi budidaya ikan gurami di Kecamatan Dukupuntang Kabupaten Cirebon. Universitas Pendidikan Indonesia.

Malika, U. E., Tejasari, \& Hani, E. S (2012). Perumusan strategi peningkatan mutu teknik produksi ikan gurami (Osphronemus gouramy) berdasarkan Metode Force Field Analysis (FFA). Jsep, 6(1), 12-19.

Ponce-Marban, D., Hernandez, J. M., \& Gasca-Leyva, E. (2006). Simulating the economic viability of Nile tilapia and Australian redclaw crayfish polyculture in Yucatan, Mexico. Aquaculture, 261, 151-159.

Rano, P., \& Yuningsih, S. (2018). Pengaruh penambahan probiotik EM-4 (effective microorganisme-4) dalam pakan terhadap pertumbuhan dan kelangsungan hidup ikan gurami (Osphronemus gouramy). Jurnal Akuakultur, 1(1).

Sigantang, M., \& Sarwono, B. (2005). Budidaya Gurami. Penebar Swadaya.

Soekartawi. (2005). Agribisnis teori dan aplikasinya. PT Raja Grafindo Persada. 
Tri Widayatsih, Budidaya Perikanan Skala ...

Sugiono. (2018). Metode penelitian kuantitatif, kualitatif, dan $R \& D$. Alfabeta.

Thapa, G. B., \& Niroula, G. S. (2008). Alternative options of land consolidation in the mountains of Nepal: An analysis based on stakeholders' opinions. Journal of Land Use Policy, 25, 338-350.

Verawati, Y., Muarif, \& Mumpuni, F. S. (2015). Pengaruh perbedaan padat penebaran terhadap pertumbuhan dan kelangsungan hidup benih ikan gurami (Osphronemus gouramy) pada sistem resirkulasi. Jurnal Mina Sains, 1(1), 6-12.

Virnanto, L., Rachmawatie, D., \& Samidjan, I. (2016). Pemanfaatan tepung hasil fermentasi azolla (Azolla microphylla) sebagai campuran pakan buatan untuk meningkatkan pertumbuhan dan kelulushidupan ikan gurami (Osphronemus gouramy). Journal of Aquaculture Management and Technology, 5(1), 1-7. 